zeszyt 152, 2018, 83-104

doi: 10.4467/20833113PG.17.032.8255

Instytut Geografii i Gospodarki Przestrzennej UJ

Wydawnictwo Uniwersytetu Jagiellońskiego

\title{
SIEĆ PIESZYCH SZLAKÓW TURYSTYCZNYCH W PARKU KRAJOBRAZOWYM GÓRY IZERSKIE W PÓłNOGNEJ REPUBLICE CZESKIEJ
}

\author{
Krzysztof Kotodziejczyk
}

\section{Network of hiking tourist trails in the Izerskie Mountains Landscape Park in the northern Czech Republic}

\begin{abstract}
Located in the Czech Western Sudetes, the Izerskie Mountains Landscape Park has a quite developed network of tourist trails. Among them are hiking trails, which were analysed in this article. The density of this network was examined with reference to the natural conditions, tourist attractiveness of certain parts of the park and directions of tourist movement. Using coefficients connected with the graph theory the connectivity and the type of the network was defined. The course of the trails was analysed in comparison with the distribution of the most valuable areas (nature reserves), tourist infrastructure was also taken into account. Besides methods connected with the graph theory the analysis of tourist maps (including comparative analysis of maps from different periods) and results of field studies focused on inventory of types of trail's surface and connected infrastructure were used in the paper. A stress was laid on changes introduced in the network in recent years (new trails and changes of course of those already existing), which resulted in reduction in the length of sections having asphalt or concrete surface and sections of combined course of trails intended for different forms of tourism. The network of hiking trails in the Izerskie Mountains Landscape Park can be assessed as proper and being a source of some good standards.
\end{abstract}

Keywords: hiking tourist trails, graph theory, landscape park, the Izerskie Mountains

Zarys treści: Położony w czeskich Sudetach Zachodnich Park Krajobrazowy Góry Izerskie cechuje się rozbudowaną siecią tras turystycznych, z których analizie zostały poddane szlaki 
piesze. Prześledzono ich gęstość w odniesieniu do warunków naturalnych, atrakcyjności turystycznej poszczególnych części parku i kierunków przemieszczania się turystów. Korzystając ze wskaźników zaczerpniętych z teorii grafów, określono spójność i typ sieci. Zanalizowano przebieg szlaków w stosunku do rozmieszczenia obszarów najcenniejszych przyrodniczo (rezerwatów), uwzględniono też zagospodarowanie turystyczne. W pracy wykorzystano ponadto analizę map turystycznych (w tym analizę porównawczą map z różnych okresów) oraz wyniki prac terenowych, polegających na inwentaryzacji typów nawierzchni szlaków i infrastruktury z nimi związanej. W dyskusji położono szczególny nacisk na wprowadzane w ostatnich latach zmiany w rozwoju sieci (nowe szlaki i zmiany przebiegu już istniejących), które spowodowały, że ograniczono długość odcinków prowadzących po drogach asfaltowych lub betonowych oraz pokrywających się z trasami przeznaczonymi dla innych form turystyki. W konkluzjach stwierdzono między innymi, że sieć szlaków pieszych Parku Krajobrazowego Góry Izerskie można uznać za wzorcową z punktu widzenia społecznego udostępniania wartości krajoznawczych regionu.

Stowa kluczowe: piesze szlaki turystyczne, teoria grafów, park krajobrazowy, Góry Izerskie

\section{Wprowadzenie}

Czeska część Gór Izerskich prawie w całości objęta jest granicami Chráněnej krajinnej oblasti (CHKO) Jizerské hory, którą - biorąc pod uwagę rygory ochrony i sposób udostępnienia obszaru turystom - można uznać za odpowiednik polskiego parku krajobrazowego (por. Faracik 2012). Poza dominującymi pod względem powierzchni terenami górskimi pokrytymi przeważnie lasami świerkowymi lub bukowymi na jej obszarze znajdują się grunty orne i pastwiska, miejscowości i nieuciążliwy przemysł. Rolę uzupełniającą względem parku krajobrazowego w czeskich Górach Izerskich pełnią liczne rezerwaty przyrody (czes. prirodní rezervace), część zaliczana do wyższej kategorii rezerwatów narodowych (czes. národnípřirodni rezervace). Do tej ostatniej grupy należy m.in. rezerwat Jizerskohorské bučiny o powierzchni 951 ha (dodatkowo 1750 ha otuliny), powstały w 1999 r. z połączenia i rozszerzenia siedmiu rezerwatów (od zachodu): Špičák (32 ha), Stržový vrch (81 ha), Poledník (436 ha), Štolpichy (206 ha), Frýdlantské cimbuří (117 ha), Paličník (40 ha) i Tišina (42 ha) ${ }^{1}$. Jest to piąty co do wielkości rezerwat w Republice Czeskiej (Woźniak 2006), w którym - poza roślinnością (głównie dolnoreglowymi buczynami) - chroni się także osobliwości przyrody nieożywionej (skałki, wychodnie skalne, wodospady, jary). Biorąc pod uwagę formy ochrony przyrody, w czeskiej części Gór Izerskich występuje zatem więcej restrykcji w zakresie rozwoju funkcji turystycznej niż w polskiej, gdzie znajdują się tylko dwa rezerwaty (rozległy - Torfowiska Doliny Izery² i niewielki - Krokusy

\footnotetext{
${ }^{1}$ Wymienione nazwy odpowiadają jednym z najważniejszych formacji skałkowych i jednocześnie punktów widokowych na analizowanym obszarze.

${ }^{2}$ Ma on swój odpowiednik po czeskiej stronie granicy, także odznaczający się znaczną powierzchnią.
} 
w Górzyńcu), a obszar pasma jest częścią sieci Natura 2000, ponadto posiada rangę Leśnego Kompleksu Promocyjnego. Pomimo tego sieć szlaków turystycznych, zarówno pieszych, jak i rowerowych (w niniejszym artykule brane pod uwagę będą tylko te pierwsze) jest po czeskiej stronie granicy bardziej rozbudowana. Warto więc poddać analizie ich przebieg (także w zakresie rozmieszczenia obszarów chronionych) oraz sposób zagospodarowania.

Czeski fragment Gór Izerskich jest pod wieloma względami inny niż polski. Zasadnicza, centralna, część także odznacza się niewielkimi deniwelacjami (główna wierzchowina na wysokości około 950 m n.p.m.; Warszyńska 2000), łagodnymi, kopulastymi szczytami oraz pokryciem lasami świerkowymi i torfowiskami. Ale nawet tu występuje kilka śmiałych kulminacji (np. Jizera, 1122 m n.p.m., drugi najwyższy szczyt czeskiej części pasma) i wyraźnie liczniejsze są skałki. O specyfice omawianego obszaru świadczą jednak jego krawędziowe fragmenty, a zwłaszcza krawędź północna o wysokości względnej dochodzącej nawet do 600 m, stromo opadająca ku dolinie rzeki Smědy i Pogórzu Izerskiemu, zwanemu przez Czechów „Frýdlantska pahorkatina". Krawędź ta jest założona na trzeciorzędowym uskoku tektonicznym (Woźniak 2006), a jej obecna rzeźba jest wynikiem rozcinania przez potoki i selektywnego wietrzenia, które wypreparowało na stokach liczne granitowe skałki. Na krawędzi północnej znajdują się najatrakcyjniejsze punkty widokowe, wodospady (w tym najwyższy w Górach Izerskich Vodopád Velkého Štolpichu) i głęboko wcięte doliny. Trzeba jednak podkreślić, że także południowa część pasma dzięki porozcinaniu przez liczne cieki odznacza się znacznymi deniwelacjami. Obszar ten jest dość intensywnie zagospodarowany przez człowieka, czego wyrazem są wysoko położone miejscowości i sztuczne jeziora zaporowe. Nie uległ on tak znacznemu wyludnieniu jak niektóre fragmenty polskich Gór Izerskich (por. Migoń 2005). W efekcie - poza walorami przyrodniczymi i krajobrazowymi - cechuje się on także znacznymi walorami kulturowymi: zabytkowe kościoły, w tym ośrodek pielgrzymkowy w Hejnicach u podnóża północnej krawędzi, ślady po dawnej działalności gospodarczej, m.in. produkcji szkła, zabudowa uzdrowiskowa w Lázniach Libverda (znanych już od XIV w.), Jablonec nad Nisou słynący z produkcji biżuterii (tradycja od XIX w.).

Czeskie Góry Izerskie są nadal relatywnie rzadko odwiedzane przez polskich turystów. Być może wynika to ze słabej jak dotąd promocji tego obszaru (ostatnio przygotowano co prawda materiały promocyjne wspólnie ze Świeradowem-Zdrojem, ale wcześniej tego typu inicjatyw brakowało), ale znaczenie może mieć też sąsiedztwo z Karkonoszami, pozostającymi - w powszechnej świadomości - obszarem bardziej interesującym, oraz dość duża atrakcyjność polskiej części Gór Izerskich (zwłaszcza po wybudowaniu kolei gondolowej na Stóg Izerski). Z reguły z tej części czeskich Sudetów kojarzone są dwa miasta: Frýdlant z wielokrotnie przebudowywanym i powiększanym zamkiem, z którym związany jest słynny Albrecht z Valdštejna, oraz Liberec z neorenesansowym ratuszem, najstarszym w Republice Czeskiej ogrodem 
zoologicznym i górującą nad zabudowaniami górą Ještěd (1012 m n.p.m.) z wieżą telewizyjną. Miejsca te jednak położone są już poza obszarem Gór Izerskich.

\section{Cel pracy i metody badań}

Celem artykułu jest analiza sieci szlaków pieszych w czeskim Parku Krajobrazowym Góry Izerskie pod względem ich przebiegu, charakteru nawierzchni, pokrywania się z trasami przeznaczonymi dla innych grup turystów (w szczególności dla rowerzystów) oraz zagospodarowania turystycznego. W przypadku przebiegu wykorzystana została teoria grafów i zaczerpnięte z niej wskaźniki topologicznej analizy struktury przestrzennej. Przyjęto, że każdy węzeł szlaków jest wierzchołkiem grafu płaskiego nieskierowanego, odcinki zaś między węzłami - krawędziami (pomija się tu sytuację, gdy tą samą drogą prowadzą dwa szlaki tego samego typu). Nawiązując do prac Styperka (2001, 2002), wykorzystano następujące wskaźniki (Potrykowski, Taylor 1982): - wskaźnik Kansky’ego $\beta=$ e/v, gdzie e - liczba krawędzi, v - liczba wierzchołków (im wyższe wartości współczynnika $\beta$, tym większa spójność sieci);

- wskaźnik Kansky'ego $\gamma=$ e/[3(v-2)] (jest to stosunek istniejącej liczby krawędzi do maksymalnej możliwej liczby krawędzi wynikającej z liczby wierzchołków; wartości tego wskaźnika zawierają się w przedziale od 0 przy całkowitym braku spójności do 1, gdy istnieją wszystkie możliwe krawędzie);

- wskaźnik $\alpha=\mu /(2 v-5)$, gdzie $\mu$ to liczba cyklomatyczna obliczana ze wzoru $\mu=\mathrm{e}-\mathrm{v}+\mathrm{p}$, przy czym $\mathrm{p}$ to liczba izolowanych podgrafów.

W przypadku pozostałych zagadnień podstawą pracy była analiza map turystycznych (w tym analiza porównawcza map z różnych okresów) oraz prace terenowe, polegające na inwentaryzacji charakteru nawierzchni i infrastruktury powiązanej z trasami. Dużą wagę przywiązano do wprowadzanych w ostatnich latach zmian przebiegu niektórych szlaków oraz rozbudowy sieci w mniej frekwentowanych dotychczas częściach pasma. Jeśli chodzi o bazę turystyczną, analizowano jej przeznaczenie, rozmieszczenie w ramach sieci szlaków, wielkość i stan techniczny. Jako zagospodarowanie szlaków w niniejszym opracowaniu traktowano infrastrukturę zlokalizowaną bezpośrednio przy szlaku. Rozpatrywano zwłaszcza urządzenia związane z informacją o pokonywanej trasie (oznakowanie, drogowskazy, tablice informacyjne i dydaktyczne), zagospodarowanie miejsc odpoczynkowych (ławki, stoły, wiaty i zadaszenia, schrony przeciwdeszczowe) oraz przystosowanie walorów do zwiedzania (schody, pomosty, kładki, barierki, zabezpieczenia przejść, informacja o obiektach). Badania objęły też powiązaną ze szlakami przestrzennie i funkcjonalnie bazę noclegową i gastronomiczną. 


\section{Gęstość i spójność sieci szlaków pieszych}

Sieć szlaków pieszych w Parku Krajobrazowym Góry Izerskie (ryc. 1) jest dość nierównomiernie rozwinięta. Jej gęstość zależy od szeregu czynników: rzeźby i pokrycia terenu (w drugim aspekcie kluczową rolę odgrywa występowanie torfowisk i innych obszarów podmokłych), układu dróg, oddalenia od miejscowości oraz charakteru tych osad, atrakcyjności turystycznej obszaru (głównie obecność skałek i punktów widokowych), a także od rozmieszczenia na obszarze parku krajobrazowego innych form ochrony przyrody o ograniczonej dostępności (przede wszystkim rezerwaty). W efekcie najmniej rozbudowaną siecią szlaków charakteryzuje się wschodnia część parku (teren między Smědavą, Jizerką i Kořenovem; ryc. 1), gdzie rzeźba terenu jest słabo zróżnicowana (wysokości w granicach 850-1000 m n.p.m.) i występują rozległe torfowiska (największe wzdłuż rzeki Izery i jej prawego dopływu - Jizerki), chronione jako ścisłe rezerwaty przyrody. Niewiele jest tu skałek, a punkty widokowe - poza powulkanicznym Bukovcem (1005 m n.p.m.) - w związku z niewielkim wyniesieniem ponad otoczenie zapewniają tylko ograniczone możliwości podziwiania krajobrazu. Na obszarze tym dość gęsta jest sieć dróg, przy czym w dużym stopniu pokryte są asfaltem, co razem z ich monotonnym przebiegiem nie czyni ich zbyt atrakcyjnymi dla turystów pieszych. Za to, wykorzystując je, wyznaczono kilka szlaków rowerowych, których zagęszczenie we wschodniej części badanego obszaru jest dość duże. Jedynym miejscem, gdzie sieć szlaków pieszych w tym fragmencie parku jest bardziej rozbudowana, jest otoczenie turystycznej wsi Jizerka. Zbiegają się tam cztery szlaki zwykłe, a dodatkowo została wyznaczona ścieżka dydaktyczna prowadząca na torfowisko Jizerki, szczyt wspomnianego Bukowca i do doliny Izery, gdzie dzięki drewnianemu mostowi można przejść na polską stronę granicy do osady Orle ze schroniskiem turystycznym.

Mniejszą gęstością sieci odznacza się także - co może być zaskakujące - centralny fragment czeskich Gór Izerskich na południe i południowy zachód od najwyższej w tej części góry Jizera (ryc. 1). W tym przypadku decyduje o tym również umiarkowanie zróżnicowana rzeźba terenu (choć jest ona bardziej dynamiczna niż w wyżej opisanej części parku), mała liczba skałek i widoków, monotonny przebieg dróg, ale przede wszystkim - oddalenie od miejscowości. Głównymi źródłami ruchu turystycznego w czeskich Górach Izerskich są bowiem miejscowości położone po ich północnej i południowej stronie. Istnieje tylko jedna ogólnodostępna droga przecinająca pasmo trasa z Hejnic przez Bílý Potok, Smědavę̧3, Souš do Desnej (na odcinku Smědava-Souš zimą zamknięta). Przejście gór w kierunku południkowym wymaga więc pokonania

\footnotetext{
${ }^{3}$ Do Smědavy przez większość roku dociera autobus z Frýdlantu przez Hejnice (latem codziennie i z dobrą częstotliwością, poza tym jeden kurs rano w weekendy). Pozwala on uniknąć stromego podejścia i rozpocząć wędrówkę z centralnej części pasma. Brak niestety podobnego połączenia z południowej strony gór.
} 


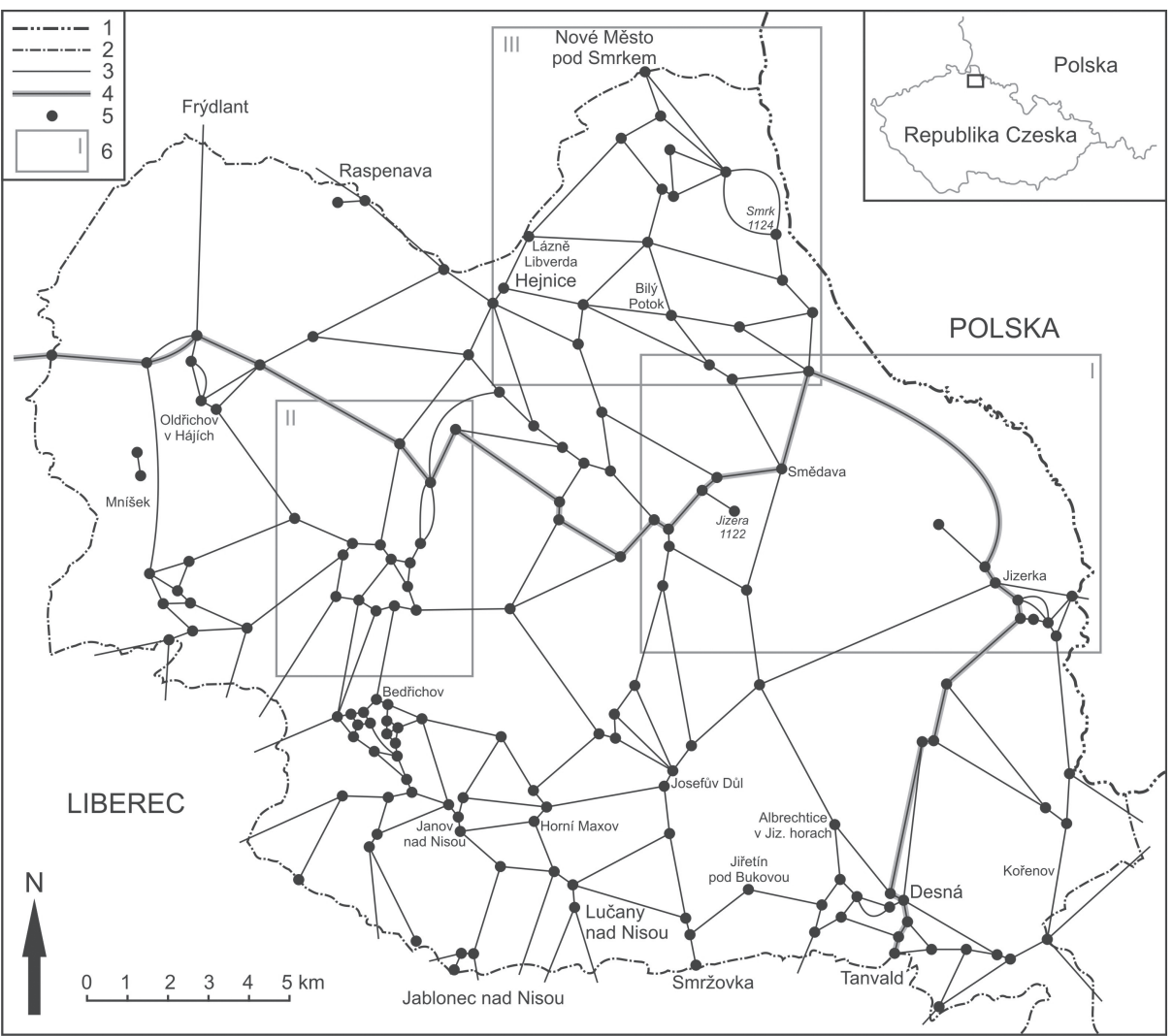

Ryc. 1. Schemat sieci szlaków pieszych w Parku Krajobrazowym Góry Izerskie, uwzględniający szlaki zwykłe, lokalne i ścieżki dydaktyczne

Fig. 1. Schema of hiking trails network in the Izerskie Mountains Landscape Park showing regular, local and educational trails

Objaśnienia: 1 - granica państwowa; 2 - granice Parku Krajobrazowego Góry Izerskie; 3 - odcinki szlaków pieszych; 4 - przebieg Szlaku Grzbietowego; 5 - węzły szlaków pieszych; 6 - zasięgi bardziej szczegółowych map (I - okolice Jizerki i Smědavy, ryc. 2; II - okolice zalewu Bedřichov, ryc. 3; III - okolice Novego Města pod Smrkem i Bílego Potoku, ryc. 4).

Explanations: 1 - national border; 2 - borders of the Izerskie Mountains Landscape Park; 3 - sections of hiking trails; 4 - route of the Ridge Trail; 5 - intersections of hiking trails; 6 - extents of more detailed maps (I - area of Jizerka and Smědava, fig. 2; II - the area of Bedřichov water-reservoir, fig. 3; III - area of Nové Město pod Smrkem and Bílý Potok, fig. 4).

Źródto: opracowanie własne na podstawie: Jizerské hory... (2015); www.mapy.cz (8.03.2017).

Source: author's own elaboration based on: Jizerské hory... (2015); www.mapy.cz (8.03.2017). 
przynajmniej kilkunastu kilometrów, przy czym środkowa część marszu będzie wyraźnie mniej atrakcyjna. Problemem jest też powrót do miejsca rozpoczęcia wędrówki wymagający objechania całego pasma od zachodu, co zajmuje około 1-2 godz. W rezultacie turyści piesi koncentrują się głównie na obrzeżach Gór Izerskich, czemu odpowiada sieć szlaków dla nich przewidzianych (rowerzyści dzięki większej prędkości przemieszczenia się częściej przekraczają pasmo z północy na południe lub jadą wzdłuż wierzchowiny). Mniejszą gęstość sieci szlaków pieszych w zachodniej części badanego parku krajobrazowego można z kolei tłumaczyć peryferyjnym położeniem i objęciem tu granicami parku także fragmentu północnego przedpola gór (Pogórze Izerskie), które posiada mniej atrakcyjną rzeźbę terenu oraz pokryta jest łąkami i polami uprawnymi. W związku z tym ta część jest mniej atrakcyjna turystycznie, choć do wyjątków należą okolice wsi Oldřichov v Hájích z licznymi formami skałkowymi i otoczenie Liberca z kilkoma punktami widokowymi, czemu odpowiadają liczniejsze szlaki piesze (w tym dwie ścieżki dydaktyczne), choć trasy koło głównego miasta regionu stanowią przede wszystkim cel spacerów jego mieszkańców.

Gęstszą sieć szlaków pieszych posiada północna i południowa część badanego obszaru (ryc. 1). W pierwszym przypadku wiąże się to ze wspomnianą wyżej krawędzią Gór Izerskich, którą opadają one ku Pogórzu Izerskiemu (przebiega na południe od Raspenavy, Hejnic i Bílego Potoku). Do zlokalizowanych tu skałek, skalnych miast, punktów widokowych i wodospadów doprowadzono liczne znakowane trasy, które biegną zarówno wzdłuż krawędzi (u jej podnóża, stokiem lub ponad nią), jak i ją przecinają. Typowe dla tego obszaru są ślepo zakończone szlaki dojściowe. Dość duża liczba znakowanych tras występuje też na stokach najwyższego szczytu czeskich Gór Izerskich - Smrku (1124 m n.p.m.), sprowadzając do Novego Města pod Smrkem, Hejnic lub Bílego Potoku. Jest to obszar wyraźnie mniej atrakcyjny niż wspomniana krawędź (większe znaczenie ma tu jedynie dziedzictwo kulturowe związane z kopalnictwem), na którym jednak w ostatnich latach wyznaczono wiele nowych tras (por. ryc. 4). Wynika to zapewne ze wzniesienia na szczycie Smrku wieży widokowej, co wzmogło ruch turystyczny, ale też z chęci stworzenia alternatywy dla licznie odwiedzanych terenów leżących bardziej na południe oraz nadania funkcji turystycznej Novemu Městu, które po upadku lokalnego przemysłu boryka się z dużym bezrobociem i odpływem mieszkańców. W południowej części Gór Izerskich rzeźba terenu także jest bardziej dynamiczna, choć nie ma tu wyraźnej krawędzi. O charakterze rzeźby decydują głębokie doliny Nysy Łużyckiej, Kamienicy i Izery wraz z dopływami. Na szczytach znajdują się liczne punkty widokowe wzbogacone pięcioma wieżami widokowymi (pięć kolejnych położonych jest w bliskim sąsiedztwie parku krajobrazowego). Te walory wraz z istnieniem dużej strefy zabudowanej składającej się z kilku miast i wsi (m.in. konurbacja Liberec-Jablonec nad Nisou, Smržovka, Tanvald) zdecydowały o wyznaczeniu tu licznych szlaków pieszych (ryc. 1). 
Często są to jednak szlaki lokalne (spacerowe) wokół miejscowości. Niektóre osady położone w tej okolicy, ale wyżej, w górach, pełnią typowo turystyczne funkcje. Wokół nich rozwinęła się szczególnie gęsta sieć szlaków. Zwraca uwagę Josefův Důl, w którym zbiegają się szlaki wiodące z dziesięciu kierunków, Janov nad Nisou (trasy z ośmiu kierunków), a przede wszystkim Bedřichov, w którym do zwiększenia liczby węzłów szlaków przyczynia się istnienie dwóch lokalnych tras spacerowych.

Przedstawienie sieci szlaków turystycznych jako grafu ma na celu jej uproszczenie (co stanowi ułatwienie podczas analizy zagęszczenia sieci) oraz służy określeniu stopnia jej rozwinięcia i spójności. Na podstawie przedstawionych wyżej wzorów wyliczono wartości podstawowych wskaźników grafowych dla sieci szlaków w czeskim Parku Krajobrazowych Góry Izerskie i porównano je z wcześniej uzyskanymi (Kołodziejczyk 2015b) wynikami dla polskiej części pasma (tab. 1). Biorąc pod uwagę liczbę węzłów (wierzchołków) i odcinków szlaków pomiędzy nimi (krawędzi), oferta szlaków pieszych w czeskiej części jest bardziej rozbudowana, przy czym wynika to m.in. z większej powierzchni, choć - jak zaznaczono wyżej - zagęszczenie szlaków jest tu rzeczywiście większe niż po polskiej stronie granicy. Okazuje się jednak, że pod względem innych wskaźników sieci te są bardzo podobne. Można uznać je za umiarkowanie spójne, na co wskazują wartości wskaźnika $\beta$ (tab. 1) zbliżone lub nieco wyższe niż w innych pasmach Sudetów czy obszarach chronionych Republiki Czeskiej (np. CHKO Czeski Raj $\beta=1,33$, Park Narodowy Podyjí $\beta=1,24$; por. Kołodziejczyk 2015b). Warto też dodać, że wyniki dla obu części Gór Izerskich są bardzo zbliżone do wyliczonej przez Styperka $(2001)^{4}$ wartości tego wskaźnika dla polskiego Karkonoskiego Parku Narodowego $(\beta=1,38)$. Biorąc pod uwagę inny reżim ochronny tych obszarów, sieć szlaków pieszych w Karkonoszach jest zbyt rozbudowana, a w Górach Izerskich powinna ulec zagęszczeniu. Badany obszar może bowiem stanowić alternatywę dla niezwykle popularnego wśród turystów najwyższego pasma Sudetów, pod warunkiem jednak że turyści będą mieli tu zapewnioną konkurencyjną ofertę. Ograniczeniem są tutaj jednak wspominane już rozległe torfowiska, strome stoki w częściach krawędziowych oraz umiarkowana atrakcyjność krajobrazu w centralnej części pasma. Na badanym obszarze istnieje nieco mniej niż połowa spośród potencjalnych połączeń wynikających z liczby węzłów szlaków $(\gamma=0,47)$. Jest to kolejne potwierdzenie umiarkowanej spójności sieci, przy czym ograniczeniem w jej zwiększaniu są wyżej wymienione czynniki. Po obu stronach granicy istnieją też podobne możliwości urządzania wycieczek w formie pętli, na co wskazują wartości wskaźnika $\alpha$ (tab. 1).

Znając wartości wskaźników $\alpha$ i $\gamma$ (tab. 1), można zakwalifikować daną sieć szlaków do jednego z typów kształtów sieci zaproponowanych przez Taafee i Gauthiera

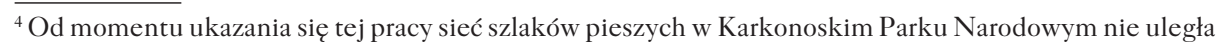
większym zmianom, które istotnie wpływałyby na wartość wskaźnika. 
Tab. 1. Porównanie wskaźników charakteryzujących sieci szlaków pieszych w Parku Krajobrazowym Góry Izerskie w Republice Czeskiej i polskiej części Gór Izerskich

Table 1. Comparison of coefficients characterising networks of hiking trails in the Izerskie Mountains Landscape Park in the Czech Republic and in the Polish part of the Izerskie Mountains

\begin{tabular}{|l|c|c|}
\hline \multirow{2}{*}{\multicolumn{1}{|c|}{$\begin{array}{c}\text { Wskaźnik } \\
\text { Coefficient }\end{array}$}} & $\begin{array}{c}\text { Park Krajobrazowy Góry Izerskie } \\
\text { (Republika Czeska) } \\
\text { The Izerskie Mountains } \\
\text { Landscape Park (Czech Republic) }\end{array}$ & $\begin{array}{c}\text { Wartości / Values } \\
\text { Polska czéść Gór Izerskich (rozpatrywana } \\
\text { P granicach regionu fizycznogeograficznego) } \\
\text { Polish part of the Izerskie Mountains (analysed } \\
\text { within borders of the physical geographic region) }\end{array}$ \\
\cline { 2 - 3 } & 162 & 42 \\
\hline $\begin{array}{l}\text { Liczba wierzchołków } \\
\text { Number of nodes }\end{array}$ & 226 & 58 \\
\hline $\begin{array}{l}\text { Liczba krawędzi } \\
\text { Number of sections }\end{array}$ & 1,40 & 1,38 \\
\hline $\begin{array}{l}\text { Wskaźnik Kansky'ego } \beta \\
\text { Kansky } \beta \text { coefficient }\end{array}$ & 0,47 & 0,48 \\
\hline $\begin{array}{l}\text { Wskaźnik Kansky'ego } \gamma \\
\text { Kansky } \gamma \text { coefficient }\end{array}$ & 66 & 17 \\
\hline $\begin{array}{l}\text { Liczba cyklomatyczna } \mu \\
\mu \text { cyclomatic number }\end{array}$ & 0,21 & 0,22 \\
\hline $\begin{array}{l}\text { Wskaźnik } \alpha \\
\alpha \text { coefficient }\end{array}$ & & \\
\hline
\end{tabular}

Źródto: opracowanie własne oraz na podstawie: Kołodziejczyk (2015b).

Source: author's own elaboration and based on: Kołodziejczyk (2015b).

(1973): najsłabiej rozwiniętego i spójnego układu rdzeniowego (główna trasa wraz z dojściami), układu kratowego lub układu delta (wszystkie możliwe połączenia między węzłami). Styperek (2001) dodatkowo wyróżnił układ przejściowy między układem rdzeniowym a kratowym, nazwany przez niego układem rdzeniowo-kratowym. W tym przypadku wartości wskaźnika $\gamma$ odpowiadają jeszcze układowi rdzeniowemu, zaś wartości wskaźnika $\alpha$ - już układowi kratowemu. Do tej właśnie kategorii zalicza się sieć szlaków pieszych Parku Krajobrazowego Gór Izerskich. Trzeba jednak podkreślić, że lokalnie można mówić o układzie kratowym (północny fragment pasma w okolicach Hejnic i Bílego Potoku, większość południowej części regionu), a nawet o układzie pośrednim między kratowym a delta (okolice Bedřichova i Desnej; ryc. 1), przy czym wynika to z istnienia tam szlaków lokalnych (spacerowych), wyznaczonych jako odpowiedź na większą liczbę turystów i rekreantów (mieszkańcy pobliskich miast, zwłaszcza Liberca), a niekoniecznie jest wyrazem wyższej atrakcyjności obszaru. 


\section{Przebieg szlaków pieszych a rezerwaty przyrody}

Jak zaznaczono wyżej, na terenie analizowanego parku krajobrazowego znajdują się liczne rezerwaty przyrody, niektóre wyróżniające się znaczną powierzchnią. Część z nich ma charakter ścisły (zwłaszcza obejmujące torfowiska, np. Rašeliniště Jizery, Quarré, Nová louka) i turyści nie mają do nich wstępu, a szlaki turystyczne przebiegają co najwyżej wzdłuż krótkich odcinków ich granic (ryc. 2, 3). Inne rezerwaty są udostępniane do zwiedzania, ale charakterystyczne dla badanego obszaru jest wprowadzanie na ich teren tylko krótkich, ślepo zakończonych szlaków dojściowych lub bocznic znakowanych tras przebiegających w otoczeniu. Taka sytuacja występuje w rezerwacie Prales Jizera, obejmującym las iglasty porastający kopułę szczytową tej góry. Doprowadza do niego tylko ślepo zakończony szlak żółty, zaczynający się przy obiegającym górę głównym szlaku czerwonym, a kończący się na szczycie, z którego trzeba wrócić tą samą drogą (ryc. 2). Taki układ szlaków występuje zwłaszcza w rezerwatach torfowiskowych, gdzie do krajobrazowo najatrakcyjniejszych fragmentów wybudowano drewniane kładki (np. rezerwaty Rašeliniště Jizerky, Klečové louky czy Na Čihadle, gdzie dodatkowo wzniesiono drewnianą wieżę obserwacyjną; ryc. 2). Rezerwat Černá hora jest przecięty na odcinku 0,6 km przez szlak żółty, który poza tym przebiega wzdłuż jego granic (kolejne $0,6 \mathrm{~km}$ ), a do położonych tu skałek i punktów widokowych doprowadzają dwie krótkie bocznice, także pokrywające się w większości z granicami obszaru chronionego (łącznie następne 0,5 km). Trzeba jednak podkreślić, że często dość korzystny z perspektywy ochrony przyrody przebieg

Ryc. 2. Zmiany sieci szlaków pieszych w północno-wschodniej części Parku Krajobrazowego Góry Izerskie między rokiem 2010 (A) a rokiem 2017 (B)

Fig. 2. Changes in the network of hiking trails in the north-eastern part of the Izerskie Mountains Landscape Park between 2010 (A) and 2017 (B)

Objaśnienia: 1 - granica państwowa; 2 - granice rezerwatów przyrody; 3 - czerwone szlaki piesze; 4 - niebieskie szlaki piesze; 5 - zielone szlaki piesze; 6 - żółte szlaki piesze; 7 - odcinki szlaków przebiegające drogami asfaltowymi lub betonowymi; 8 - ścieżki dydaktyczne; 9 - obiekty gastronomiczne poza miejscowościami.

Explanations: 1 - national border; 2 - borders of nature reserves; 3 - hiking trails marked red; 4 - hiking trails marked blue; 5 - hiking trails marked green; 6 - hiking trails marked yellow; 7 - sections of hiking trails using asphalt or concrete tracks; 8 - educational trails; 9 - catering services beyond settlements.

Źródto: opracowanie własne na podstawie: Gemeinde Mirsk... b.r.w.; Jizerské hory... (2015), www.mapy.cz (8.03.2017).

Source: author's own elaboration based on: Gemeinde Mirsk... b.r.w.; Jizerské hory... (2015), www.mapy.cz (8.03.2017). 
szlaków wynika z układu dróg, do którego nawiązują także granice rezerwatów. Jednocześnie przypadki przecinania tych cenniejszych fragmentów przez trasy piesze to niejednokrotnie także skutek przebiegu istniejących dróg leśnych, zwłaszcza na obszarach podmokłych, gdzie nie ma innej możliwości poprowadzenia znakowanej trasy.

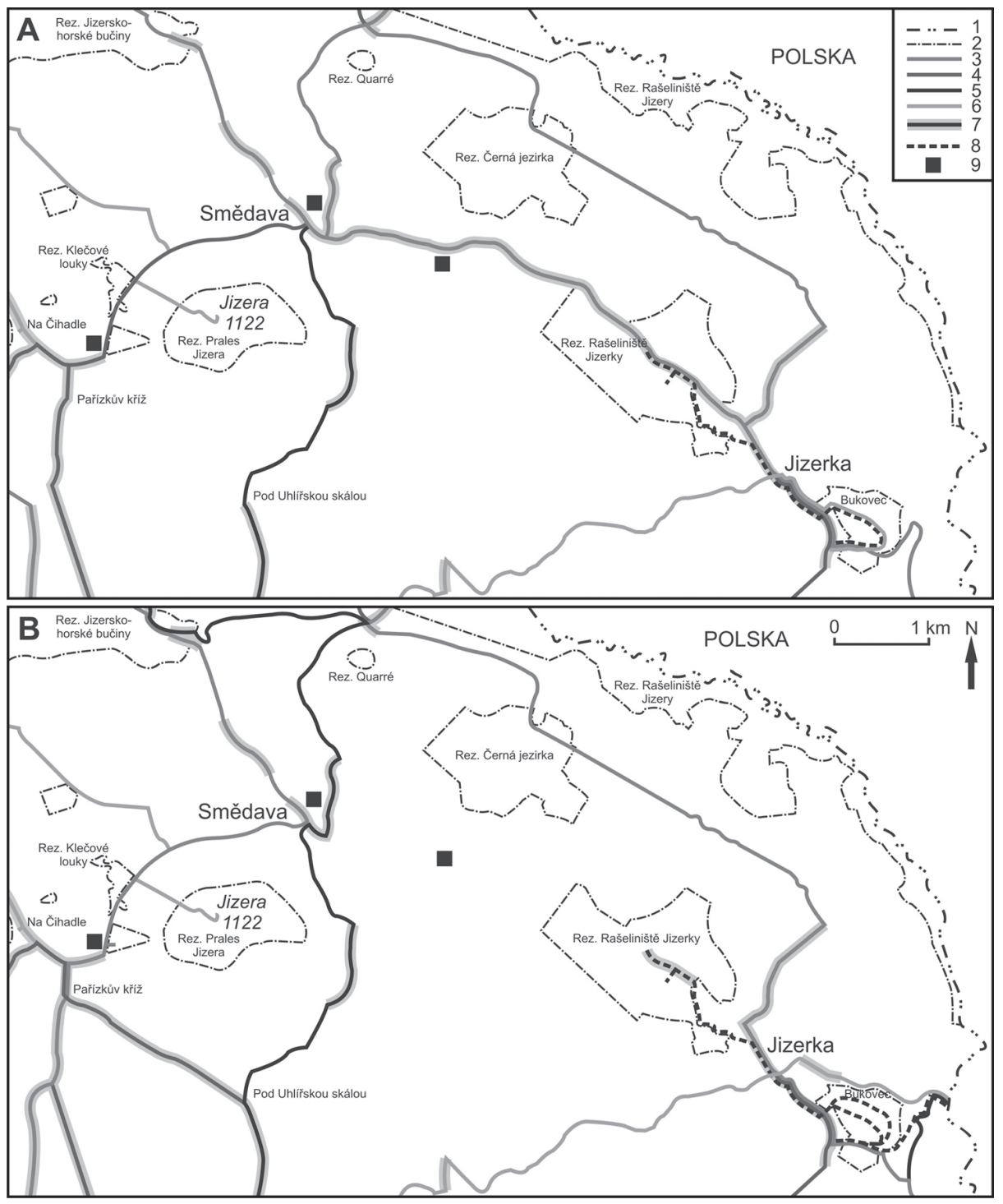




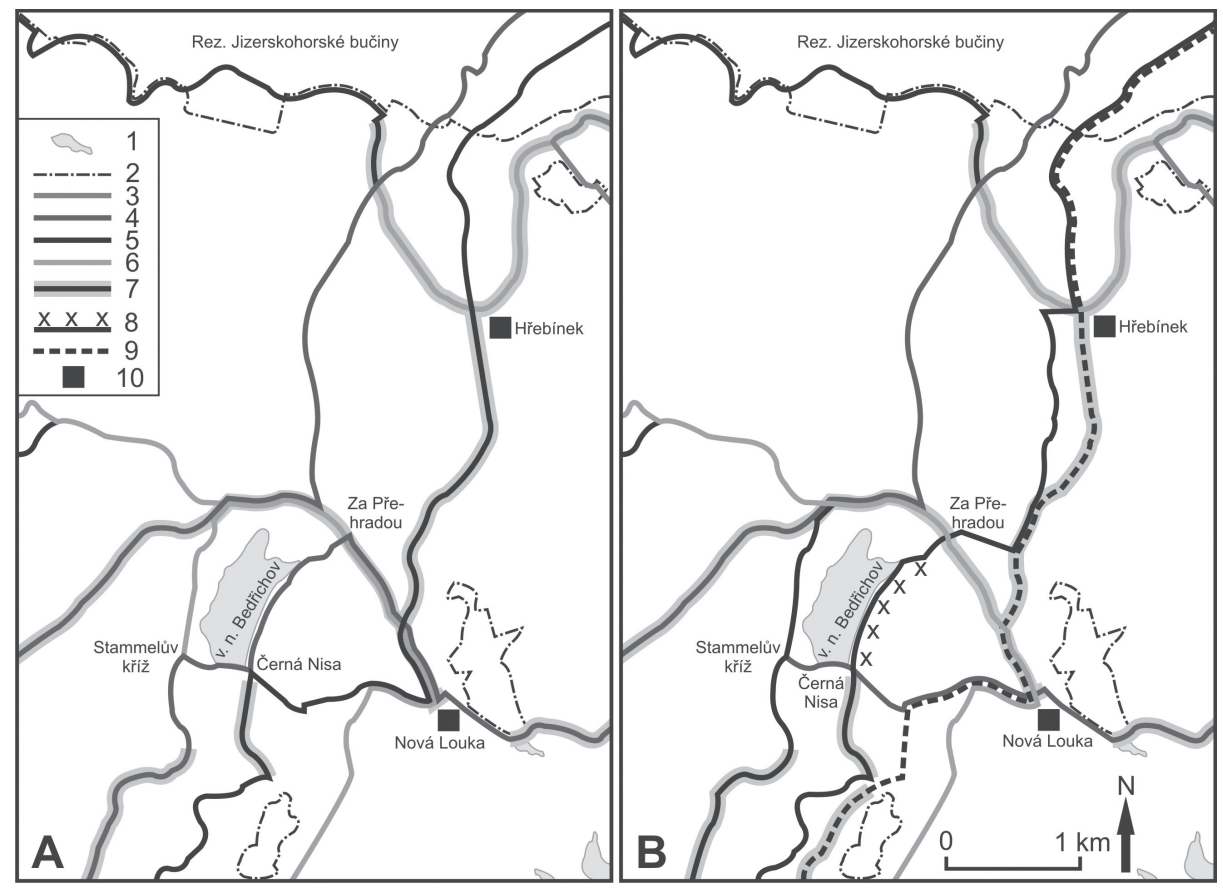

Ryc. 3. Zmiany sieci szlaków pieszych w otoczeniu zalewu Bedřichov w zachodniej części Parku Krajobrazowego Góry Izerskie między rokiem 2012 (A) a rokiem 2017 (B)

Fig. 3. Changes in the network of hiking trails in the vicinity of the Bedřichov water-reservoir in the western part of the Izerskie Mountains Landscape Park between 2012 (A) and 2017 (B) Objaśnienia: 1 -zbiorniki wodne; 2 - granice rezerwatów przyrody; 3 -czerwone szlaki piesze; 4 -niebieskie szlaki piesze; 5 -zielone szlaki piesze; 6 - żółte szlaki piesze; 7 - odcinki szlaków przebiegające drogami asfaltowymi lub betonowymi; 8 - odcinki szlaków przystosowane do potrzeb osób poruszających się na wózkach inwalidzkich; 9 - ścieżki dydaktyczne; 10 - obiekty gastronomiczne poza miejscowościami.

Explanations: 1 - water-reservoirs; 2 - borders of nature reserves; 3 - hiking trails marked red; 4 - hiking trails marked blue; 5 - hiking trails marked green; 6 - hiking trails marked yellow; 7 - sections of hiking trails using asphalt or concrete tracks; 8 - sections of trails adjusted to the needs of people moving on wheelchairs; 9 - educational trails; 10 - catering services beyond settlements.

Źródto: opracowanie własne na podstawie: Górne Łużyce... (2012); Jizerské hory... (2015), www.mapy.cz (8.03.2017).

Source: author's own elaboration based on: Górne Łużyce... (2012); Jizerské hory... (2015), www.mapy.cz (8.03.2017). 
Analiza relacji między przebiegiem szlaków pieszych i rozmieszczeniem rezerwatów musi też uwzględniać zależności czasowe. Upraszczając, można założyć, że na badanym terenie najstarsza jest sieć dróg, która nawiązuje - przynajmniej częściowo do dawnych traktów handlowych i wynika z prowadzonej od wieków gospodarki leśnej. Szlaki turystyczne są młodszą formą zagospodarowania, gdyż najstarsze na tym terenie tworzono w XIX w. i na początku XX w. ${ }^{5}$ Obecna sieć - zwłaszcza w pobliżu krawędzi lub w partiach szczytowych - do tych przedwojennych szlaków nawiązuje. Rezerwaty natomiast były na tym obszarze tworzone $\mathrm{z}$ reguły dopiero po II wojnie światowej. Pomimo tego - jak zaznaczono wyżej - relacje szlaków do granic rezerwatów trzeba uznać za dość korzystne. Wyjątkiem jest bardzo rozległy i jednocześnie nowy rezerwat Jizerskohorské bučiny, który powstał z połączenia i powiększenia kilku starszych. Jego obszar zdecydowanie częściej niż w innych przypadkach przecinany jest przez szlaki piesze (ryc. 3; ryc. 4). Wynika to jednak z jego wysokiej atrakcyjności turystycznej - obejmuje północną krawędź Gór Izerskich z wychodniami skał, punktami widokowymi, wodospadami i lasami bukowymi. Rezerwatem z bardzo gęstą siecią szlaków jest też Bukovec (ryc. 2), przy czym decyduje o tym przede wszystkim ścieżka dydaktyczna.

\section{Zmiany przebiegu szlaków pieszych}

W ostatnich latach sieć szlaków pieszych w czeskich Górach Izerskich ulega licznym przekształceniom. Mamy do czynienia zarówno z wyznaczaniem zupełnie nowych tras, jak i ze zmianami przebiegu tych już istniejących. W pierwszym przypadku wpisuje się to w preferowane uczynienie badanego obszaru alternatywą dla Karkonoszy. Nowo powstające szlaki może nie są tak atrakcyjne jak dotychczasowe, ale skutkują zagęszczeniem sieci, co ułatwia planowanie wędrówki. W drugim przypadku zmiany mają na celu ograniczenie odcinków szlaków pieszych przebiegających drogami o nawierzchni asfaltowej lub betonowej, uniknięcie pokrywania się z sobą szlaków pieszych i rowerowych, a także - przynajmniej częściowo - wykluczenie niekorzystnych sytuacji, gdy z jednego węzła znaki tego samego koloru rozchodzą się w więcej niż dwóch kierunkach. Taka sytuacja jest przez czeską instrukcję znakowania szlaków dopuszczana (Marking... b.r.w.; Značení... 1985), gdy liczba szlaków na jakimś obszarze jest zbyt duża względem czterech kolorów służących ich wyznaczaniu (czerwony, niebieski, zielony, żółty), ale raczej w przypadkach, gdy mamy do czynienia z przynajmniej jedną trasą posiadającą nazwę własną, co teoretycznie umożliwia rozróżnienie szlaków. W czeskich Górach Izerskich kilkakrotnie dotyczyło

\footnotetext{
${ }^{5}$ Zagospodarowywaniem Gór Izerskich po południowej stronie granicy przed 1945 r. zajmowało się m.in. założone w 1884 r. Niemieckie Górskie Towarzystwo Ještědu i Gór Izerskich (niem. Deutscher Gebirgsverein für das Jeschken- und Isergebirge (Potocki 2004).
} 


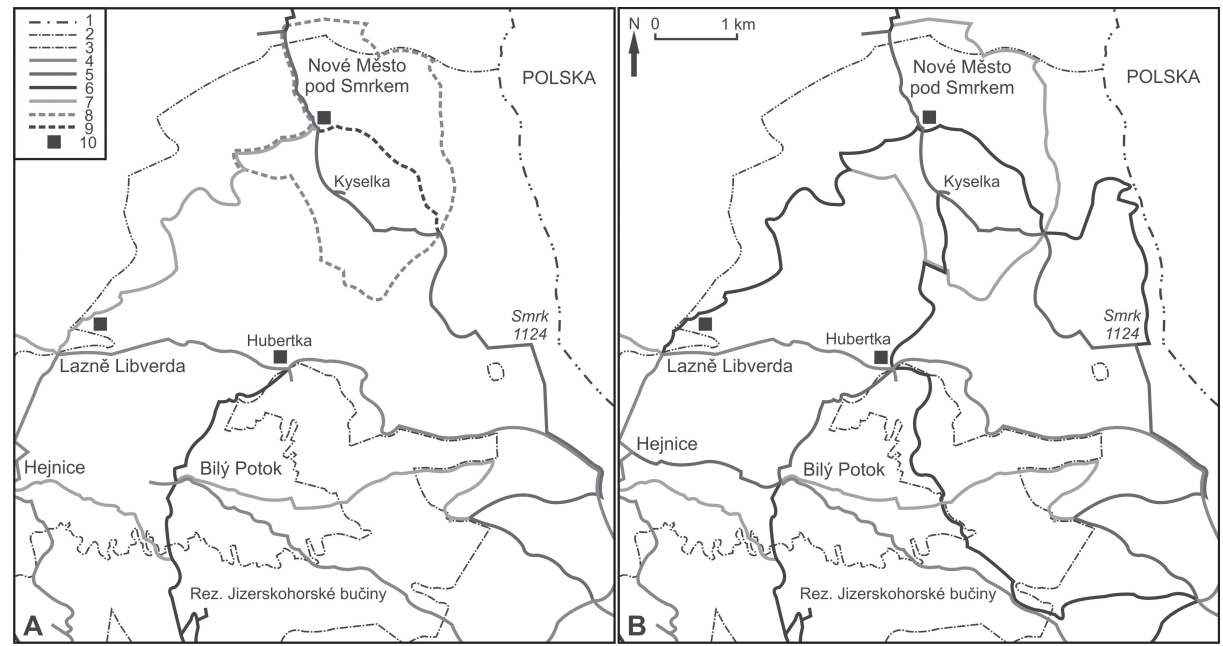

Ryc. 4. Zmiany sieci szlaków pieszych w północnej części Parku Krajobrazowego Góry Izerskie między rokiem 2010 (A) a rokiem 2017 (B)

Fig. 4. Changes in the network of hiking trails in the northern part of the Izerskie Mountains Landscape Park between 2010 (A) and 2017 (B)

Objaśnienia: 1 - granica państwowa; 2 - granice Parku Krajobrazowego Góry Izerskie; 3 - granice rezerwatów przyrody; 4 - czerwone szlaki piesze; 5 - niebieskie szlaki piesze; 6 - zielone szlaki piesze; 7 -żółte szlaki piesze; 8 - czerwone lokalne szlaki piesze; 9 - zielone lokalne szlaki piesze; 10 - obiekty gastronomiczne poza miejscowościami

Explanations: 1 - national border; 2 - borders of the Izerskie Mountains Landscape Park; 3 - borders of nature reserves; 4 - hiking trails marked red; 5 - hiking trails marked blue; 6 - hiking trails marked green; 7 - hiking trails marked yellow; 8 - local hiking trails marked red; 9 - local hiking trails marked green; 10 - catering services beyond settlements.

Źródło: opracowanie własne na podstawie: Gemeinde Mirsk... b.r.w.; Jizerské hory... (2015); www.mapy.cz (8.03.2017).

Source: author's own elaboration based on: Gemeinde Mirsk... b.r.w.; Jizerské hory... (2015); www.mapy.cz (8.03.2017).

to szlaków nienazwanych, ale zostało obecnie wyeliminowane. Taki układ szlaków może bowiem wprowadzać turystów w błąd, zwłaszcza gdy nie korzystają z dokładnej mapy. Szczególnie dużo zmian w sieci szlaków pieszych w ostatnich latach nastąpiło w okolicach: górskich osad Smědava i Jizerka we wschodniej części parku krajobrazowego (ryc. 2), zalewu Bedřichov w części zachodniej (ryc. 3) i na stokach Smrku na północy analizowanego obszaru (ryc. 4). 
Większość zmian przebiegu szlaków pieszych była nastawiona na ograniczenie długości odcinków przebiegających drogami asfaltowymi lub betonowymi. Takie drogi są niestety bardzo częste w czeskich górach, a były tworzone głównie w czasach komunistycznych w celu ułatwienia gospodarki leśnej. Przyczyniła się do tego też klęska ekologiczna w Sudetach w latach 80. XX w., kiedy niezbędny stał się dostęp ciężkiego sprzętu w głąb obumierających kompleksów leśnych (Staffa 1992). Ogólnie uznaje się, że podczas wyznaczania szlaków pieszych powinno się unikać dróg o nawierzchni twardej (asfaltowych, betonowych, brukowanych), co najwyżej można je wykorzystywać na krótkich dystansach lub w przypadku konieczności zachowania ciągłości szlaków długodystansowych (Herz 1985). Wędrówka po takiej nawierzchni nie jest korzystna dla ludzkiej stopy, ponadto upodabnia marsz górski do przemieszczania się po obszarach zabudowanych, co zaprzecza idei turystki aktywnej (Frankowski 1966; Gajewski 2007). Zmiany w tym zakresie po pierwsze polegały na likwidacji tras, np. 5-km odcinka szlaku czerwonego między Smědavą a Jizerką, który w całości miał nawierzchnię asfaltową, a ponadto pokrywał się z główną (krajową) trasą rowerową (ryc. 2). Po drugie - na przesunięciu szlaku z drogi asfaltowej na równoległą gruntową lub nawet wąską ścieżkę, co np. uczyniono w przypadku zielonego szlaku doprowadzającego od południa do węzła szlaków Hřebínek (ryc. 3). W przypadku tej trasy wprowadzono w ogóle większe zmiany, dzięki którym obecnie między węzłami Černá Nisa i Hřebínek prowadzi drogą asfaltową na odcinku tylko $0,4 \mathrm{~km}$, a w 2012 r. było to aż 3,3 km. Podobne zmiany dotyczyły sąsiedniego szlaku niebieskiego, gdzie między węzłami Černá Nisa i Nová louka w ogóle uniknięto sztucznej nawierzchni (w 2012 r. było to 1,3 km). Nowe szlaki także często nie prowadzą drogami asfaltowymi, choć z racji ich zagęszczenia w centralnej części pasma nie zawsze jest to możliwe (np. rejon węzła Pařízkův kříž; niestety obok zlikwidowano fragment szlaku czerwonego prowadzącego ścieżką gruntową; ryc. 2).

Drugim problemem związanym z siecią szlaków w Parku Krajobrazowym Góry Izerskie jest pokrywanie się z sobą szlaków przeznaczonych dla różnych użytkowników - pieszych z rowerowymi i pieszych z narciarskimi ${ }^{6}$. Obie sytuacje nie są pożądane, gdyż z racji różnej prędkości przemieszczania się może dojść do wypadków, obniża się też komfort obu grup, np. turyści piesi muszą schodzić z drogi rowerzystom, ci drudzy zaś w takich sytuacjach muszą zwalniać (zimą dodatkowym problemem jest niszczenie przez piechurów tzw. śladów dla nart biegowych). Ponieważ prowadziłem swoje badania w okresie letnim, skupiłem się tylko na zależnościach między szlakami

\footnotetext{
${ }^{6}$ Centralna część czeskich Gór Izerskich dzięki znacznej wysokości bezwzględnej, a jednocześnie niewielkim wysokościom względnym i dobrym warunkom śniegowym, jest popularnym miejscem uprawiania narciarstwa biegowego (podobne warunki jak w polskich Jakuszycach). Wyrazem tego jest fakt, że do górskiej osady Smědava także zimą dociera regularny autobus. Trasy biegowe nie mają tu oznaczeń typowych dla szlaków turystycznych, ale są utrzymywane przez założenie tzw. śladu.
} 
pieszymi i rowerowymi. Te drugie wykorzystują przede wszystkim leśne drogi asfaltowe, choć zdarzają się też odcinki o nawierzchni szutrowej i ziemnej. Przedstawione powyżej zmiany mające na celu ograniczenie odcinków szlaków pieszych wiodących drogami asfaltowymi przyczyniły się też więc do zmniejszenia problemu pokrywania się ich z trasami rowerowymi. Nadal jednak odcinki wspólne mają długość do kilku kilometrów, np. gdy idziemy szlakami pieszymi poprowadzonymi ponad północną krawędzią Gór Izerskich, cały czas towarzyszy nam szlak rowerowy (odległość $7,2 \mathrm{~km}$ ) a jeśli będziemy kontynuowali wędrówkę w kierunku wschodnim, do podnóża Jizery, to będzie to dodatkowo 2,1 km (ryc. 2, 3). Szlak niebieski między zalewem Bedřichov (węzeł Stammelův kř́íž) a podnóżem Jizery (węzeł Pod Uhlîrskou skálou) ma łącznie 12,3 km, z czego na długości $8 \mathrm{~km}$ pokrywa się z nim szlak rowerowy (krótko nawet dwa). Problem bezpieczeństwa w przypadku wspólnego przebiegu szlaków pieszych i rowerowych nie jest jednak aż tak znaczący na szerokich duktach i drogach leśnych, co na wąskich ścieżkach, gdzie piechur nie zawsze ma jak ustąpić drogi rozpędzonemu rowerowi. Niestety tworząc sieć tras typu MTB (ang. mountain biking) na stokach Smrku, zwaną Singltrek pod Smrkem (Kołodziejczyk 2014), kilkakrotnie wyznaczono szlak rowerowy wzdłuż wcześniej już istniejącego pieszego. W tym przypadku rowerzyści mogą poruszać się naprawdę szybko (strome zjazdy). Co prawda ustawiono odpowiednie znaki ostrzegawcze o takich odcinkach, ale sytuacji tej nie można uznać za właściwą. Tym bardziej że dotyczy tras pieszych w okolicy uzdrowiska Lázně Libverda, którymi mogą wędrować mniej sprawni piechurzy. Wspólny przebieg tras dla turystów pieszych i rowerowych jest częstszy w centralnej części Gór Izerskich, gdzie większy jest udział duktów i dróg asfaltowych, a wyraźnie mniejszy w strefach krawędziowych (poza stokami Smrku), gdzie oba typy szlaków wykorzystują inny rodzaj dróg - rowerowe biegną duktami trawersującymi stoki, szlaki piesze zaś - ścieżkami prowadzącymi w przybliżeniu prostopadle do poziomic, wśród skał, w terenie o zróżnicowanej rzeźbie.

Nowe odcinki szlaków powstały w szczególności na stokach Smrku na obszarze między miejscowościami Hejnice, Bílý Potok i Nové Město pod Smrkem (ryc. 4). Porównując sytuację w 2010 i 2017 r., łatwo zauważyć, że powstało wiele dodatkowych połączeń, których w sieci brakowało. Znakowanymi trasami można teraz przejść z Bílego Potoku do Novego Města bez konieczności - jak dawniej - wspinania się na szczyt Smrku lub schodzenia do Hejnic lub Lázni Libverda. Pozwala na to nowy szlak od schroniska Hubertka ${ }^{7}$ do źródła Kyselka koło Novego Města. Ten sam szlak, wiodąc w przybliżeniu na podobnej wysokości, spina teraz cztery trasy sprowadzające z wyższych partii Gór Izerskich (leżących w pobliżu granicy państwowej) na ich północne przedpole. Łączy także wspomniane wyżej schronisko z podobnym obiektem powyżej Bílego Potoku (Bartlova bouda). Za jego wadę należy jednak

\footnotetext{
${ }^{7}$ W pobliżu schroniska Hubertka w grupie skalnej Kočičí kameny powstała krótka trasa typu via ferrata.
} 
uznać to, że na łącznej długości 4,8 km prowadzi drogami asfaltowymi, w większości jednak leśnymi. Wyznaczono też nowy szlak między Bílym Potokiem a Hejnicami. Obie miejscowości łączą się zabudową i oczywiście możliwe jest przejście pomiędzy nimi szosą. Dodatkowy szlak proponuje jednak alternatywę w postaci dróg polnych ciągnących się po północnej stronie obszaru zabudowanego. W ostatnim czasie powstała także kolejna znakowana trasa na szczyt Smrku oraz zreorganizowano układ szlaków w bezpośrednim otoczeniu Novego Města, zastępując szlaki lokalne o niestandardowym znakowaniu zwykłymi. Kiedy w 2010 r. zdobycie Smrku przy założeniu rozpoczęcia i zakończenia wędrówki w tej samej miejscowości wiązało się z powrotem w większości tą samą drogą, którą przebiegała wędrówka w górę, to obecnie z każdego kierunku istnieje kilka wariantów tras.

Nową ofertą jest również tzw. Szlak Grzbietowy (niem. Kammweg, czes. Hřebenovka; ryc. 1), który powstał w ramach współpracy transgranicznej i łączy czeskie Góry Izerskie z Górami Łużyckimi po obu stronach granicy. Jest to nawiązanie do najdłuższej przedwojennej znakowanej trasy w Czechach, która wiodła z niemieckiego Blankenstein an der Saale przez m.in. Rudawy, Czeską Szwajcarię, Ještěd, Góry Izerskie, Karkonosze, Góry Orlickie, Masyw Śnieżnika aż na szczyt Pradziada (Hřebenovka... 2013). Został wyznaczony w latach 1902-1903 tylko do Śnieżki, następnie w latach 20. XX w. przedłużony do Adršpachu (Potocki 2004). Nowa jego wersja na obszarze Parku Krajobrazowego Góry Izerskie łączy najwyższe szczyty, m.in. Špičák (724 m n.p.m.), Poledník (864 m n.p.m.), Ptačí vrchy (1013 m n.p.m.), Holubník (1071 m n.p.m.), Černą horę (1055 m n.p.m.), Pytlácké kameny (975 m n.p.m.) i Jelení stráň (1018 m n.p.m.). Doprowadza też do wielu punktów widokowych i innych atrakcji (formy skałkowe, torfowiska, ruiny zamku). Jest on odpowiedzią na brak głównego szlaku, który ciągnąłby się równoleżnikowo wzdłuż najwyższych fragmentów pasma. Większość szlaków przecina je bowiem w układzie zbliżonym do południkowego, a spinają je krótsze trasy łącznikowe. Szlak Grzbietowy, jako że powstał w już ukształtowanej sieci szlaków, nie ma odrębnego oznakowania. Jest to sugerowana trasa wykorzystująca istniejące szlaki, a jej przebieg zaznaczany jest tylko w nagłówkach kierunkowskazów na węzłach ${ }^{8}$. Warto zwrócić uwagę, że został on poprowadzony tak, by popularyzować bardziej atrakcyjne fragmenty centralnej części gór, a niekoniecznie licznie już obecnie odwiedzane północne i południowe części parku krajobrazowego. Równolegle z pieszą wersją Szlaku Grzbietowego powstał też wariant rowerowy. Starano się, by w jak najmniejszym stopniu obie te trasy pokrywały się. W Parku Krajobrazowym Gór Izerskich ma to miejsce na łącznej długości tylko $5 \mathrm{~km}$, przy łącznej długości wariantu pieszego na terenie parku wynoszącej prawie $48 \mathrm{~km}$.

\footnotetext{
${ }^{8}$ Przedwojenny Kammweg miał znaki w kształcie czterozębnego grzebienia na białym tle (Potocki 2004). Obecnie te symbole umieszczane są na kierunkowskazach szlaków, które trasa ta wykorzystuje. Ponadto pojawiają się one na tablicach informacyjnych o przebiegu szlaku.
} 
Nową wartościową ofertą w ramach sieci szlaków w Parku Krajobrazowym Góry Izerskie jest odcinek przystosowany do potrzeb osób poruszających się na wózkach inwalidzkich. Jest to fragment szlaku zielonego o długości 1,2 km między węzłami Černá Nisa i Za Přehradou, przebiegający wzdłuż wschodniego brzegu zalewu Bedřichov (ryc. 3). W ramach remontu kładek prowadzących po tamtejszym torfowisku przygotowano odpowiednio wyrównaną nawierzchnię, niewysokie krawężniki chroniące osoby z niepełnosprawnością przed zjechaniem z trasy oraz poszerzenia umożliwiające wyminięcie się dwóm wózkom (ryc. 5). Cały odcinek ma właściwą szerokość i nachylenia (łącznie z dwiema bocznicami sprowadzającymi nad wodę) ${ }^{9}$, wyposażony jest w infrastrukturę dla odpoczynku. Dojazd to tej trasy dla osób poruszających się na wózkach zapewniają asfaltowe drogi leśne od parkingu przy Šámalovej boudzie w osadzie Nová Louka, od Bedřichova lub ze wsi Fojtka na obrzeżach Liberca, choć w tym ostatnim przypadku nachylenia mogą być niezgodne ze wskazaniami i niezbędna może być pomoc opiekuna. Do zalet odcinka przygotowanego dla osób poruszających się na wózkach inwalidzkich należy zaliczyć udostępnianie w zasadzie tych samych walorów, które mogą zobaczyć osoby pełnosprawne i przygotowanie wzdłuż trasy tablic edukacyjnych, wadą zaś jest niedostateczna promocja i brak odpowiednich oznaczeń w terenie, które wskazywałyby na charakter trasy i przybliżałyby jej cechy (długość, nachylenia). By zapewnić bezpieczeństwo osobom niepełnosprawnym, obowiązuje zakaz wjazdu rowerami.

\section{Zagospodarowanie szlaków pieszych}

Czeskie Góry Izerskie wyróżniają się rozwiniętą bazą turystyczną, zwłaszcza towarzyszącą (Warszyńska 1990). Ponieważ Park Krajobrazowy Gór Izerskich obejmuje swoim zasięgiem kilkanaście miejscowości o funkcjach turystycznych (m.in. Lázně Libverda, Hejnice, Bílý Potok, Bedřichov, Josefův Důl, Jizerka), na jego terenie znajduje się wiele obiektów noclegowych i gastronomicznych. Warto jednak skupić uwagę na tych położonych poza miejscowościami. Najważniejsze są tu całoroczne obiekty o charakterze zbliżonym do schronisk turystycznych, przy czym trzeba pamiętać, że pod względem oferty gastronomicznej baza tego typu w Republice

\footnotetext{
${ }^{9}$ Szlaki przystosowane dla osób niepełnosprawnych ruchowo, w szczególności poruszających się na wózkach inwalidzkich, powinny mieć szerokość co najmniej 1,2 m (przy takiej szerokości niezbędne są mijanki i bezwzględny zakaz wjazdu dla rowerzystów), przy czym najbardziej pożądana (i bezpieczna dla użytkowników) jest szerokość ok. $2 \mathrm{~m}$. Nachylenie podjazdów dłuższych niż 1,5 m nie powinno przekraczać 6\%. W przypadku podjazdów krótszych możliwe są wyjątkowo większe spadki, natomiast na podjazdach dłuższych niż $9 \mathrm{~m}$ konieczne jest zastosowanie spoczników o długości co najmniej 1,4 m (Zadrożny 2009). Nachylenie poprzeczne ścieżki nie powinno przekraczać 2-6\%. Por. Kołodziejczyk (2013, 2015a) oraz tam wskazana literatura.
} 

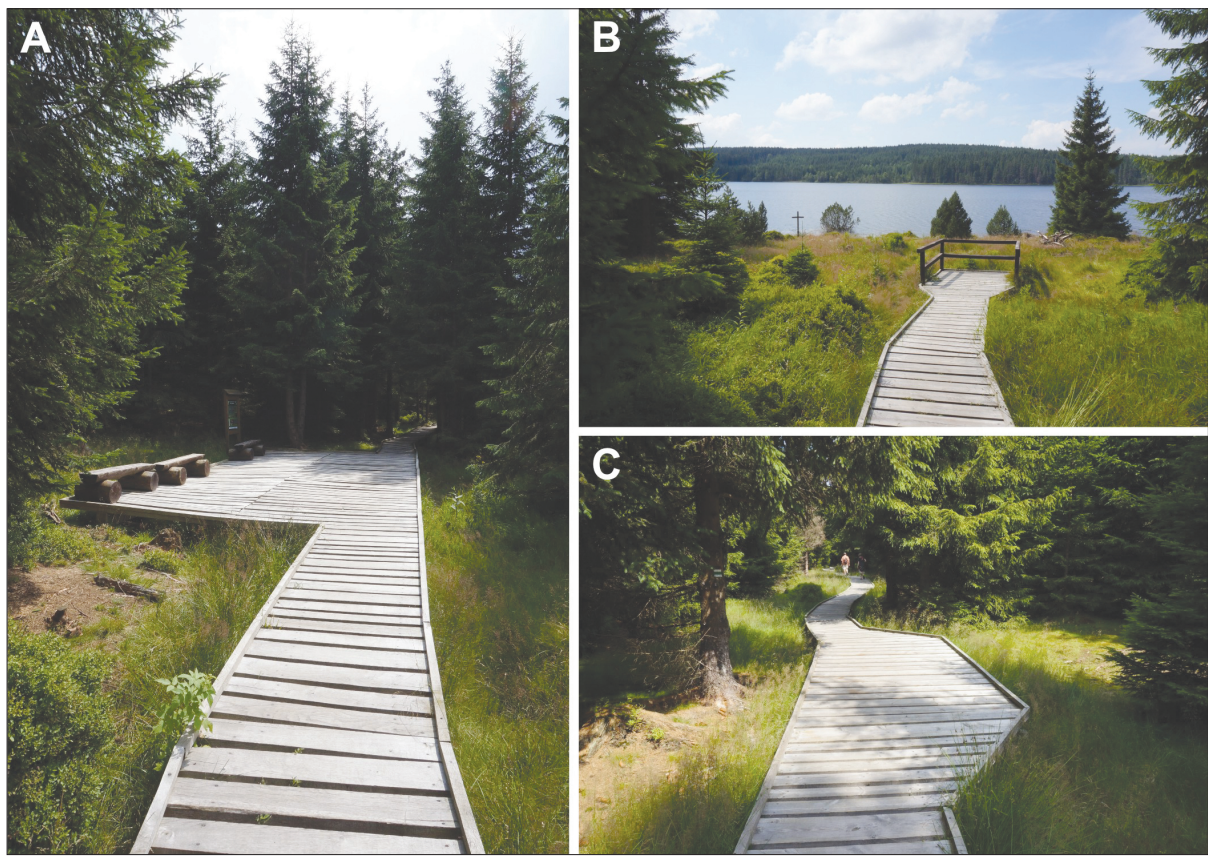

Ryc. 5. Szlak przystosowany do potrzeb osób poruszających się na wózkach inwalidzkich koło zalewu Bedřichov: A - kładka wraz z miejscem odpoczynkowym; B - bocznica doprowadzająca w pobliże zalewu; $\mathrm{C}$ - mijanka dla wózków inwalidzkich (fot. K. Kołodziejczyk)

Fig. 5. Trail adapted to the needs of people using wheelchairs near the Bedřichov waterreservoir: A - footbridge with a rest place; $\mathrm{B}$ - side-trail leading closer to the lake; $\mathrm{C}$ - loop for wheelchairs (photo by K. Kołodziejczyk) 
Czeskiej ma charakter typowych restauracji (np. brak możliwości spożywania własnej żywności). W północnej części parku znajduje się wspomniana już Hubertka (ryc. 4), w centralnej zaś - restauracja na Smědavie (ryc. 2), Š́malova bouda w Novej Louce (ryc. 3) i restauracja na Oldřichovskim sedlu ${ }^{10}$. Oddalone są one o ok. $10 \mathrm{~km}$, co zapewnia swobodę w planowaniu wędrówki. W południowej części schroniska związane są z wieżami widokowymi Královka, Slovanka i Tanvaldský Špičák, przy czym jest to obszar gęściej zabudowany i tylko w dwóch ostatnich przypadkach leżą one poza osadami. Uzupełnieniem są obiekty o zbliżonym charakterze położone w miejscowościach, z reguły w ich wyższych częściach, np. Bartlova bouda na górnym skraju Bílego Potoku (ryc. 4). Ciekawym rozwiązaniem są trzy sezonowe (letnie) kioski spożywcze, które zapewniają napoje, przekąski i ograniczony zestaw ciepłych posiłków. Wzbogacają one ofertę schronisk w centralnej części pasma, przy czym rozłożone są wzdłuż popularnej trasy wędrówek między Jizerką na wschodzie a punktami widokowymi ponad Hejnicami. Ponad Novym Městem pod Smrkem powstał też nieco większy lokal sezonowy związany z siecią tras MTB Sinlgtrek pod Smrkem (ryc. 4). Położony jest bezpośrednio przy węźle szlaków pieszych, stąd jest wykorzystywany także przez piechurów.

Pozostała infrastruktura związana ze szlakami nie budzi zastrzeżeń. Trasy są dobrze oznakowane, w każdym węźle znajduje się pełny zestaw kierunkowskazów, dość równomiernie rozmieszczone są wiaty przeciwdeszczowe i miejsca odpoczynkowe, związane z węzłami szlaków i najpopularniejszymi trasami. W rezultacie - biorąc też pod uwagę bazę gastronomiczną - turyści mają zapewnione miejsce do regeneracji sił z reguły nie rzadziej niż co $5 \mathrm{~km}$, co odpowiada ponad 1 godzinie wędrówki. Trzeba zwrócić uwagę na przystosowanie walorów do zwiedzania. Liczne są odcinki poprowadzone wśród skał po wykutych w nich stopniach lub - rzadziej - po metalowych drabinkach. Większość punktów widokowych zabezpieczonych jest barierkami. Są to ułatwienia najczęściej sprzed II wojny światowej, choć np. na Špičáku ponad Oldřichovem długi ciąg metalowych schodów zastąpił niedawno stromą i śliską ścieżkę. Wędrówkę po torfowiskach umożliwiają drewniane kładki, a podziwianie szerszych panoram - wieże widokowe. W tym ostatnim wypadku występują zarówno obiekty sprzed II wojny światowej (Královka, Slovanka, Bramberk, Tanvaldský Špičák), jak i współczesne (Smrk, niewysoka wieża nad torfowiskiem Na Čihadle). Znaczącą wartość edukacyjną mają tablice informacyjne rozstawione w różnych częściach parku, także poza ścieżkami dydaktycznymi, przybliżające turystom walory przyrodnicze terenu oraz sposoby jego przekształcania i użytkowania przez człowieka (w tym przystosowywanie na potrzeby turystyki).

${ }^{10}$ Niestety restauracja na Oldřichovskim sedlu w ostatnich latach poza sezonem letnim czynna jest tylko w wybrane dni tygodnia, zimą jedynie w weekendy. 


\section{Podsumowanie i wnioski}

Park Krajobrazowy Góry Izerskie (czes. Chráněná krajinná oblast Jizerské hory) jest jedną z wielu tego typu form ochrony krajobrazu w Republice Czeskiej. Jednym z ich podstawowych zadań jest także udostępnianie turystyczne atrakcyjnych miejsc, co realizowane jest głównie poprzez wyznaczanie szlaków turystycznych. Na analizowanym terenie sieć znakowanych tras pieszych jest dość rozbudowana, choć porównując z sąsiednimi Karkonoszami (zarówno po stronie polskiej, jak i czeskiej), jest słabiej rozwinięta. Wynika to z różnej atrakcyjności sąsiednich obszarów, ich popularności wśród turystów i historii rozwoju turystyki. Potwierdzają to współczynniki służące analizie grafów. Sieć szlaków parku krajobrazowego analizowana w takim ujęciu cechuje się niezbyt dużą spójnością - istnieje mniej niż połowa połączeń wynikających z obecnej liczby węzłów. Skutkuje to ograniczonymi możliwościami planowania wycieczek, zwłaszcza okólnych (z powrotem w miejsce startu), co wynika głównie z ukształtowania terenu i występowania terenów podmokłych. Sytuacja jednak i tak jest lepsza niż w polskiej części Gór Izerskich, gdzie długość szlaków pieszych (proporcjonalnie do powierzchni) jest mniejsza. Należy podkreślić wiele pozytywnych zmian, jakie wprowadzono w ostatnich latach po czeskiej stronie granicy. Po pierwsze, wyznaczono nowe szlaki lub przedłużono już istniejące, dzięki czemu poprawiła się oferta dla piechurów, zwłaszcza w północnej części regionu (masyw Smrku, na którego szczycie wzniesiono wieżę widokową, co przyciągnęło tu wielu turystów). Po drugie, zmieniono przebieg kilku znakowanych tras, zmniejszając udział odcinków prowadzących po niekorzystnych dla turystów pieszych drogach o utwardzonej nawierzchni i pokrywających się ze szlakami rowerowymi, co jest potencjalnie niebezpieczne i może ograniczać komfort przemieszczania się dla obu stron. Można uznać, że obecnie sieć szlaków pieszych Parku Krajobrazowego Góry Izerskie w efektywny sposób udostępnia tutejsze walory krajobrazowe i krajoznawcze.

Szlaki turystyczne są jedną z podstawowych form udostępniania obszarów chronionych, z jednej strony ułatwiając turystom penetrację danego terenu, ale z drugiej - kanalizując ruch turystyczny. $\mathrm{Na}$ obszarach bardziej cennych przyrodniczo, a zwłaszcza takich, gdzie przyroda jest podatna na zniszczenie, sieć szlaków powinna być mniej rozbudowana, a na terenach nie tak wartościowych, bardziej odpornych, sieć szlaków może być gęstsza (warto jednak, żeby były to miejsca atrakcyjne pod względem krajobrazowym). Chociaż Park Krajobrazowy Góry Izerskie nie jest obszarem chronionym o wysokim reżimie, to w jego obrębie znajdują się tereny podlegającej ochronie rezerwatowej, w tym rezerwaty ścisłe. Trzeba podkreślić, że tutejsza sieć szlaków turystycznych wyraźnie odpowiada tym zależnościom. Znakowane trasy rzadko wprowadzają do wnętrza rezerwatów, co najwyżej stworzono ślepo zakończone szlaki dojściowe do pewnych reprezentatywnych (i ewentualnie 
atrakcyjnych wizualnie) miejsc, kilka odcinków szlaków przebiega też wzdłuż ich granic. Wyjątek stanowi największy na tym terenie rezerwat Jizerskohorské bučiny, który został utworzony dopiero w 1999 r., czyli już po ukształtowaniu zasadniczego kształtu sieci. Ponadto na jego obszarze znajdują się jedne z głównych atrakcji pasma i trudno sobie wyobrazić, by ograniczać do nich dostęp. Niewielki udział odcinków szlaków prowadzących przez rezerwaty wynika nie tylko z odpowiedniego planowania infrastruktury turystycznej, ale także z pokrycia terenu - występowania torfowisk i innych podmokłych miejsc, jak również z układu dróg. Niemniej, przebieg szlaków na badanym terenie w stosunku do rozmieszczenia obszarów szczególnie cennych przyrodniczo należy uznać za korzystny.

\section{Literatura}

Faracik R., 2012, Czechy, [w:] W. Kurek (red.), Regiony turystyczne swiata, cz. 1, Wydawnictwo Naukowe PWN, Warszawa, 225-231.

Frankowski A., 1966, Budowa górskich ścieżek turystycznych, „Wierchy”, 35, 220-222.

Gajewski J., 2007, Nikłym śladem perci, czyli szlaki górskie wczoraj i dzis, [w:] P. Kuleczka (red.), Szlaki turystyczne a przestræen turystyczna, Zarząd Główny PTTK, Warszawa, 191-199.

Gemeinde Mirsk - Friedeberg im Isergebirge: Maßstab 1:50 000, b.r.w., Wydawnictwo Turystyczne Plan, Jelenia Góra.

Górne Łużyce, Styk Trzech Granic: skala 1: 75 000, 2012, Wydawnictwo Turystyczne Plan, Jelenia Góra.

Herz L., 1985, Znakowane szlaki turystyczne w Kampinoskim Parku Narodowym, „Chrońmy Przyrodę Ojczystą", 41 (3), 44-51.

Hřbenovka. Kammweg, 2013, Geoprint, Liberec-Görlitz.

Jizerské hory, Frýdlantsko: turistická mapa 1: 40 000, 2015, SHOCart, Vizovice.

Kołodziejczyk K., 2013, Szlaki turystyczne przystosowane do potrzeb osób niepetnosprawnych doświadczenia polskie i czeskie, próba stworzenia wzorca, [w:] R. Wiluś, J. Wojciechowska (red.), Warsztaty z Geografii Tury zmu, tom 3, Nowe-stare formy turystyki w przestrzeni, Wydawnictwo Uniwersytetu Łódzkiego, Łódź, 287-306.

Kołodziejczyk K., 2014, Singltrek pod Smrkem, „Sudety. Przyroda, Kultura, Historia”, 2 (155), 22-23.

Kołodziejczyk K., 2015a, Szlaki turystycæne dla osób z niepetnosprawnościq ruchowq w Wielkiej Brytanii, [w:] A. Stasiak, J. Śledzińska, B. Włodarczyk (red.), Wczoraj, dziś i jutro turystyki aktywnej i specjalistycznej, Wydawnictwo PTTK „Kraj”, Warszawa, 317-332.

Kołodziejczyk K., 2015b, Wzorce zagospodarowania szlaków turystycznych w górach średnich na wybranych przykładach europejskich, Instytut Geografii i Rozwoju Regionalnego Uniwersytetu Wrocławskiego, Wrocław.

Marking system of the tourist trails in the Caech Republic: Marked rambling trails. Marked ski trails. Marked cycling trails, b.r.w., Klub českých turistů - ústředí, Praha. 
Migoń P., 2005, Regiony fizycznogeograficzne, [w:] J. Fabiszewski, Przyroda Dolnego Ślaska, PAN Oddział we Wrocławiu, Wrocław, 19-37.

Potocki J., 2004, Rowwój zagospodarowania turystycznego Sudetów od potowy XIX w. do II wojny swiatowej, Wydawnictwo Turystyczne Plan, Jelenia Góra.

Potrykowski M., Taylor Z., 1982, Geografia transportu. Zarys problemów, modeli i metod badawczych, PWN, Warszawa.

Staffa M., 1992, Góry a turystyka - koegzystencja czy konflikt?, „Wierchy”, 56, 5-27.

Styperek J., 2001, Piesze szlaki turystyczne w polskich parkach narodowych, Turyzm, 11 (1), 25-37.

Styperek J., 2002, Dostępność i spójność penetracyjna obszarów chronionych, [w:] J. Partyka (red.), Ü̇ytkowanie turystyczne parków narodowych. Ruch turystyczny - konflikty - zagrożenia, Instytut Ochrony Przyrody PAN, Ojcowski Park Narodowy, Ojców, 51-62.

Taafee E.J., Gauthier H.L., 1973, Geography of transportation, Prentice Hall, Englewood Cliffs. Warszyńska J., 1990, Czechostowacja, [w:] J. Warszyńska (red.), Regionalna geografia turystyczna swiata: Cą̧ś́ I - Europa i ZSRR, Uniwersytet Jagielloński, Instytut Geografii, Kraków, 332-352.

Warszyńska J., 2000, Cæechy, [w:] J. Warszyńska (red.), Geografia turystyczna swiata, cz. 1, Wydawnictwo Naukowe PWN, Warszawa, 312-322.

Woźniak M., 2006, Buczynowe góry, „Sudety. Przyroda, Kultura, Historia”, 10 (67), 30-31.

Zadrożny P., 2009, Dostępna komunikacja miejska, Fundacja Instytut Rozwoju Regionalnego, Kraków.

Značeni turistických cest. Učebni texty pro snačkaře III. třidy, 1985, Tělovýchovná Škola ČÚV ČSTV, Olimpia, Praha.

www.mapy.cz (8.03.2017).

Krzysztof Kotodziejczyk

Uniwersytet Wroctawski

Instytut Geografii i Rozwoju Regionalnego

pl. Uniwersytecki 1, 50-137 Wroctaw

krzysztof.kolodziejczyk@uwr.edu.pl 